Nutraceutic effect of free condensed tannins of Lysiloma acapulcensis (Kunth) benth on parasite infection and performance of Pelibuey sheep

Cesar García-Hernández, Javier AreceGarcía, Rolando Rojo-Rubio, German David Mendoza-Martínez, Benito Albarrán-Portillo, et al.

Tropical Animal Health and

Production

ISSN 0049-4747

Volume 49

Number 1

Trop Anim Health Prod (2017) 49:55-61

DOI 10.1007/s11250-016-1157-8
Volume 49 - Number 1 - January 2017

Tropical

Animal Health and Production
Springer

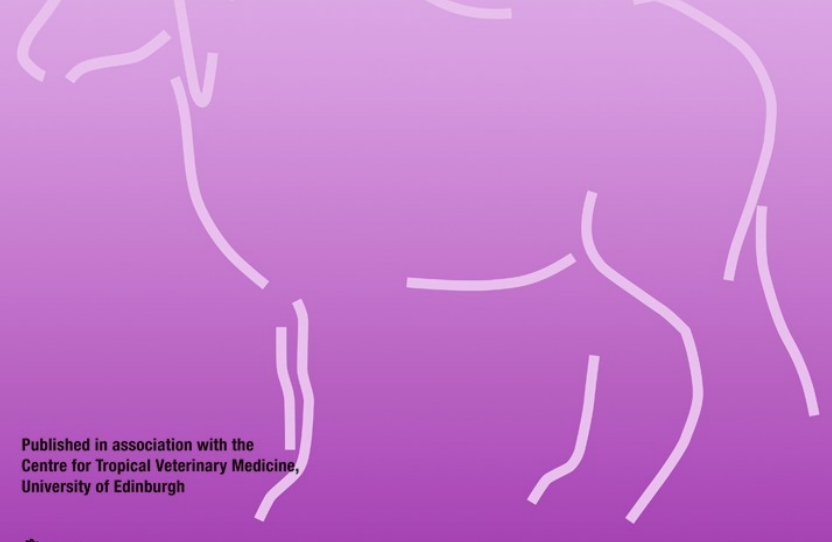

Springer 
Your article is protected by copyright and all rights are held exclusively by Springer Science +Business Media Dordrecht. This e-offprint is for personal use only and shall not be selfarchived in electronic repositories. If you wish to self-archive your article, please use the accepted manuscript version for posting on your own website. You may further deposit the accepted manuscript version in any repository, provided it is only made publicly available 12 months after official publication or later and provided acknowledgement is given to the original source of publication and a link is inserted to the published article on Springer's website. The link must be accompanied by the following text: "The final publication is available at link.springer.com". 


\title{
Nutraceutic effect of free condensed tannins of Lysiloma acapulcensis (Kunth) benth on parasite infection and performance of Pelibuey sheep
}

\author{
Cesar García-Hernández ${ }^{1}$. Javier Arece-García ${ }^{2}$ - Rolando Rojo-Rubio ${ }^{1}$ (D) \\ German David Mendoza-Martínez ${ }^{3}$. Benito Albarrán-Portillo ${ }^{1}$. \\ José Fernando Vázquez-Armijo ${ }^{1}$ Leonel Avendaño-Reyes ${ }^{4} \cdot$ Agustín Olmedo-Juárez $^{5}$. \\ Carine Marie-Magdeleine ${ }^{6}$ - Yoel López-Leyva ${ }^{2}$
}

Received: 12 May 2016 / Accepted: 15 September 2016/Published online: 7 October 2016

(C) Springer Science+Business Media Dordrecht 2016

\begin{abstract}
Forty-five Pelibuey sheep were experimentally infested with nematodes to evaluate the effect of three free condensed tannin (FCT) levels of Lysiloma acapulcensis on fecal egg counts (FECs), packed cell volumes (PCV), ocular mucosa colors (OMC), average daily gain (ADG), and adult nematode count. Five treatments were used: 12.5, 25.0, and $37.5 \mathrm{mg}$ of FCT kg$~^{-1}$ of body weight (BW); sterile water (control); and ivermectine $\left(0.22 \mathrm{mg} \mathrm{kg}^{-1}\right.$ of BW) as chemical group. The data were processed through repeated measurement analysis. Even though the three FCT doses decreased $(P<0.05)$ the FEC, the highest reduction was obtained with $37.5 \mathrm{mg} \mathrm{kg}^{-1}$ of BW. No differences were observed in PCV and OMC. Higher ADG $(P<0.05)$ was observed with $37.5 \mathrm{mg} \mathrm{kg}^{-1}$ of BW of FCT. The count of adult nematodes (females and males) in the higher dose of FCT was similar to
\end{abstract}

Rolando Rojo-Rubio

dr_rojo70@yahoo.com.mx

1 Centro Universitario UAEM Temascaltepec, Universidad Autónoma del Estado de México, Temascaltepec, México, México

2 Estación Experimental de Pastos y Forrajes "Indio Hatuey", Universidad de Matanzas, Matanzas, Cuba

3 Departamento de Producción Agrícola y Animal, Universidad Autónoma Metropolitana Xochimilco, México, México

4 Instituto de Ciencias Agrícolas, Universidad Autónoma de Baja California, México, México

5 Centro Nacional de Investigación Disciplinaria en Parasitología Veterinaria, INIFAP, México, México

6 Unité de Recherches Zootechniques, Centre INRA Antilles-Guyane, Petit Bourg, Guadeloupe, France chemical treatment. Dose of $37.5 \mathrm{mg} \mathrm{kg}^{-1}$ of BW decreased the parasite infection and improved the lamb performance. Therefore, this dose could be used as a nutraceutic product in sheep production.

Keywords Pelibuey · Sheep · Tannins · Nematodes · Lysiloma acapulcensis · Ivermectine

\section{Introduction}

Actually, the problem of resistance to pharmaceuticals by gastrointestinal nematodes (GIN) has become aggravated, representing one of the principal challenges for parasite control in small ruminants (Torres-Acosta et al. 2012; Arece et al. 2014; Cedillo et al. 2015). As an alternative to this problem, new parasite control methods have been evaluated, highlighting the use of secondary plant components (Olmedo et al. 2014; Kommuru et al. 2015; Saric et al. 2015). Thus, in vivo studies have demonstrated the effectiveness of plants rich in tannins for the reduction of the parasite load (Martínez-Ortiz de Montellano et al. 2009; Debela et al. 2012; Ahmed et al. 2014) and egg excretion by direct affectation of fertility in females (Mupeyo et al. 2011). Lysiloma acapulcensis is a perennial tree, which is abundant in the south of Mexico state. Studies have been made to evaluate its nutritive potential (Camacho et al. 2010; Olmedo et al. 2015) and in vitro studies have been made to validate its possible anti-parasitic effects in ruminants (Olmedo et al. 2014). This represents a promising alternative to chemotherapy, especially when it is used as nutraceutic alternative, which combines the effects of a reduction of the parasite infection and a better nutritional status of the animals. Therefore, the objective of the present study was 
to evaluate the effect of different levels of free condensed tannins (FCTs) of L. acapulcensis in the diet on parasite infection of experimentally infested sheep and on some bioproductive indicators.

\section{Materials and methods}

\section{Location}

The study was developed in the Estación Experimental de Pastos y Forrajes "Indio Hatuey" Cuba. Plant material of L. acapulcensis was collected in the southwestern of the State of Mexico, Mexico, with $1740 \mathrm{~m}$ asl, and subhumid climate with rains in summer (Aw) (INEGI 2014).

\section{Collection of plant material}

For the collection of the plant material, seven sites were delimited in which trees of $L$. acapulcensis were found as part of the natural vegetation. Later, during the morning, the foliage (mature and young leaves) from seven trees was collected on each site; it was taken in a thermal container with artificially cooled temperature and was carried out to the University Center UAEM Temascaltepec (CUT) for chemical analyses. A total of 49 individual samples were collected, which corresponded to seven true replicates.

\section{Processing of the plant samples}

At the laboratory, samples were dried in a forced air oven at $48^{\circ} \mathrm{C}$ during $72 \mathrm{~h}$ until constant weight was reached. Afterward, a pool was made with all the samples to attain homogeneity; then, they were ground in a Willey mill to reach a particle size of 2-mm diameter and were high vacuum packed to be transported to Cuba.

\section{Proximal chemical analysis and fractioning of the tannins in the foliage of $L$. acapulcensis}

Dry matter (DM) was determined in the samples (DM, method 934.01) along with ash (CEN, method 942.05), crude protein (CP, method 954.01) (AOAC 1997), neutral detergent fiber (NDF), and acid detergent fiber (ACF) (Van Soest et al. 1991). Condensed total tannins (CTT) were determined using the method of butanol-HCl (Terrill et al. 1992), with the modifications of López et al. (2004). The analysis of free condensed tannins (FCTs) was determined using the method reported by Porter et al. (1986) (Table 1).

\section{Animals and feed}

Forty-five Pelibuey male lambs $(21.9 \pm 1.5-\mathrm{kg}$ body weight (BW), 6 months of age) were individually housed in pens equipped with shade, feed through an automatic waterer. The lambs were dewormed (Levamisol $10 \%$ at $7.5 \mathrm{mg} / \mathrm{kg}$ of BW, LABIOFAM, Cuba) 12 days before the start of the experiment and were maintained in total enclosure. During the experimental period, all animals received a mixture of fresh fodder ad libitum composed of $50 \%$ of the sugar cane plant (Saccharum officinarum, 6 months of age) and $50 \%$ king grass (Pennisetum purpureum, clone OM-22, 60 days of regrowth); the fodder was supplied chopped to a particle size of $3 \mathrm{~cm}$. Additionally, all animals were supplemented with $400 \mathrm{~g} /$ animal/day of concentrate with $22.3 \%$ of CP (NRC 2007), fractioned in two doses (09:00 and 14:00 h). Every 15 days, adjustments were made to the dietary balance as a function of the live weight of the animals. The Animal Protection Commission and the Scientific Council of the Estación Experimental de Pastos y Forrajes Indio Hatuey approved all the procedures to be carried out with the animals.

\section{Infective larvae $\left(\mathrm{L}_{3}\right)$}

An infested animal (donor) was used with a high parasite load of a mixture of gastrointestinal strongilids (95\% Haemonchus contortus, $2 \%$ Trichostrongylus colubriformis, and $3 \%$ of Oesophagostomum columbianum) and was maintained in a metabolism cage for the collection of feces, which were used to obtain the fecal cultures (Roberts and O'Sullivan 1952) for the collection of infesting larvae. The larvae were identified, quantified, and conserved in refrigeration $\left(8^{\circ} \mathrm{C}\right)$ until the experimental infection.

\section{Treatments, experimental procedure, and measurements}

The animals were randomly distributed (Table 2) in five experimental groups: two control groups (positive and negative) and three doses $(12.5,25.0$, and $37.5 \mathrm{mg} / \mathrm{kg}$ of live weight) of FCT added to the diet every 3 days after the confirmation of an established infection. The doses were calculated based on the concentration of FCTs, for which the animals were offered daily the following amount of fodder of $L$. acapulcensis: $2.14,3.22$, and $6.5 \mathrm{~g}$ of DM. After verifying the efficacy of Levamisol $10 \%$ administered prior to the start of the experiment (12 days), the animals were infested (day zero) with 3000 larvae $\mathrm{L}_{3}$ of a mixture of GIN previously mentioned.

\section{Fecal egg count}

Every 3 days, the feces of each animal were extracted directly from the rectum for fecal egg count (FEC) determination, which 
Table 1 Chemical composition and condensed tannin profile (g/kg DM) in leaves of Lysiloma acapulcensis

\begin{tabular}{lllllllll}
\hline Specie & OM & CP & NDF & ADF & FCT & CT-CP & CT-F & TCT \\
\hline L. acapulcensis & 945.9 & 177.0 & 607.3 & 500.8 & 116.3 & 67.8 & 3.7 & 187.8 \\
\hline
\end{tabular}

$O M$ organic matter, $C P$ crude protein, $N D F$ neutral detergent fiber, $A D F$ acid detergent fiber, $F C T$ f free condensed tannins, $C T-C P$ condensed tannin-bound crude protein, $C T-F$ condensed tannin-bound fiber, $T C T$ total condensed tannins

was expressed in eggs per gram (EPG) of feces according to the McMaster technique (Arece et al. 2002).

\section{Packed cell volumes and ocular mucosa colors}

Blood was drawn by puncture of the jugular vein and deposited in tubes with EDTA as anti-coagulant for packed cell volumes (PCV) determination by microcentrifugation. Briefly, a capillary was filled and sealed at one end and, after that, was centrifuged at $12,000 \mathrm{rpm}$ during $5 \mathrm{~min}$, and the relative value occupied by the PCV was determined. OMC was determined with the color chart for the detection of anemia FAMACHA@, which has five categories, where one corresponds to an animal with bright red coloration and five to one with pale membranes (Van Wyk and Bath 2002).

\section{Measurement of live weight gain}

The animals were weighed every third day using an OHAUS$3370(100 \pm 0.050 \mathrm{~kg})$ scale to determine daily live weight gain, and health status was monitored daily.

\section{Count of adult nematodes}

With the approval of the Animal Protection Commission and the Scientific Council of the Estación Experimental de Pastos y Forrajes Indio Hatuey, five animals per group were necropsied to count all adult parasites (male and female) in abomasum.

\section{Statistical analysis}

The analysis of the information was performed using SAS ${ }^{\circledR}$ software version 9.1.3 (SAS, 2014) through the Proc Mixed,

Table 2 Description of experimental treatments

\begin{tabular}{lll}
\hline Treatment & Description & L. acapulcensis forage \\
\hline Control & Without treatment & \\
Chemical & Ivermectine $0.22 \mathrm{mg} \mathrm{kg}^{-1}$ of BW & \\
$12.5 \mathrm{FCT}$ & $12.5 \mathrm{mg} \mathrm{kg}^{-1}$ of BW of FCT & $0.107 \mathrm{~g} \mathrm{~kg}^{-1}$ of BW \\
$25.0 \mathrm{FCT}$ & $25.0 \mathrm{mg} \mathrm{kg}^{-1}$ of BW of FCT & $0.214 \mathrm{~g} \mathrm{~kg}^{-1}$ of BW \\
$37.5 \mathrm{FCT}$ & $37.5 \mathrm{mg} \mathrm{kg}^{-1}$ of BW of FCT & $0.322 \mathrm{~g} \mathrm{~kg}^{-1}$ of BW \\
\hline
\end{tabular}

FCTs free condensed tannins, $B W$ body weight in which three covariance structures were evaluated, and the unstructured (UN) covariance resulted in the best fit. Prior to this analysis, normal distribution of the data and homogeneity of the variance were verified, so it was necessary to transform the percent variable (PCV) through the $\operatorname{Arcsin} \sqrt{X}$ and the variable FEC using $\log 10(x+1)$. The differences among means were determined with the Tukey test using an error of 0.05 (Steel et al. 1997).

\section{Results}

\section{Fecal egg count}

The egg count reduction dynamic of GIN when supplemented with dehydrated foliage of $L$. acapulcensis is presented in Fig. 1. The experimental infection was carried out on day " 0 ," and a prepatent period started on day 18 post-infection for all groups. From this time, different trends of egg count reduction were observed according to the treatment group. The control group showed the highest FEC $(p<0.05)$ with respect to the other treatment groups, which demonstrates the effectiveness in reduction of the parasite infection by this plant.

\section{Packed cell volumes and ocular mucosa colors}

The principal health indicators monitored during the experiment are presented in Fig. 2. No differences $(p>0.05)$ were observed in any of these indicators during the entire experimental period. The OMC showed little variation during the experimental period and is the result of having PCV values higher than $20 \%$.

\section{Live weight gain}

Live weight gain of the animals throughout the experimental period is shown in Fig. 3. Lambs of the control group presented the worst productive behavior $(p \leq 0.05)$, while the best weight gain was found in lambs that received the highest dose of FCT $(p \leq 0.05)$ with averages higher than $120 \mathrm{~g} /$ animal/day. The low and medium groups of FCT showed similar behavior to that of the chemical group (treated with ivermectine). 
Fig. 1 Fecal egg count dynamic in the five experimental groups

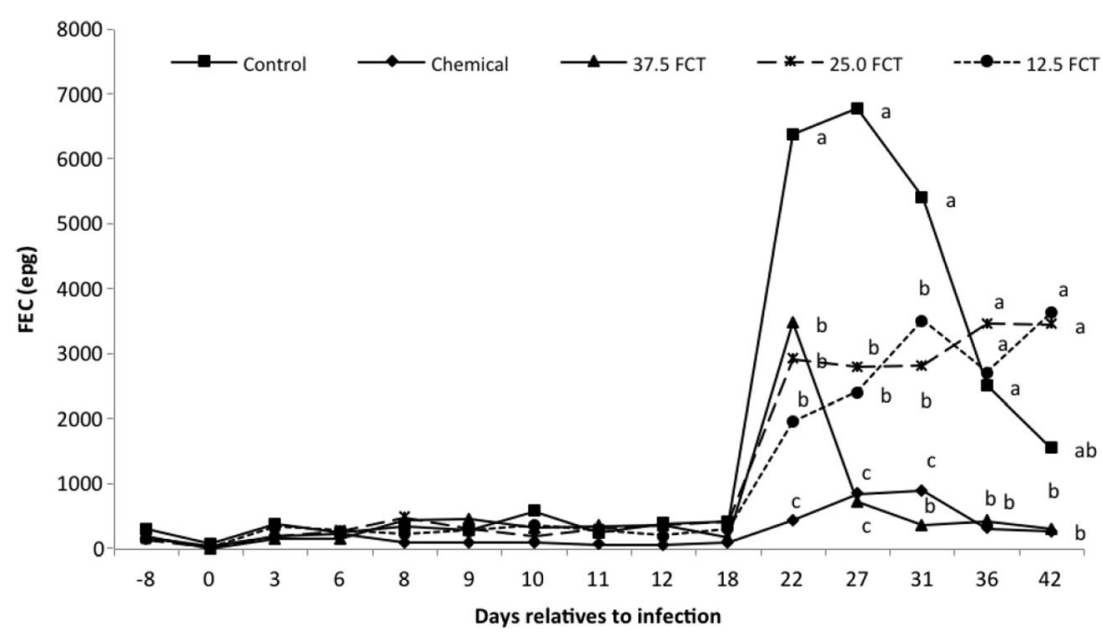

\section{Adult nematodes}

The adult nematode count in the animals is observed in Fig. 4, where the groups with the lowest doses of FCT had similar amount of parasites as the control, both in male and female parasites. The treatment of $37.5 \mathrm{mg} / \mathrm{kg}$ of BW eliminated the adult parasites at the same level as the chemical product.

\section{Discussion}

\section{Fecal egg count}

This study showed that the highest dose of FCT $\left(37.5 \mathrm{mg} / \mathrm{kg}^{-1}\right.$ of BW) had higher efficacy in the reduction of FEC, with respect to the control group. In addition, a similar trend was observed in the chemical group starting on day 27 post-infection. The intermediate and low doses also reduced the amount of eggs eliminated in feces with lower values. It is probable that higher doses of FCT had better effects on the parasites already established in the abomasum; however, it is also possible that it would have interfered with the absorption of nitrogen (Min et al. 2003). On the other hand, Olmedo et al. (2015) found a quadratic effect when 2.0, 5.0, and $7.5 \mathrm{~g}$ of FCT day ${ }^{-1}$ were used in sheep during 60 days. In addition, there are studies (Min et al. 2005) that mention that ruminal microorganisms exposed to low doses of condensed tannins have the capacity to adapt to these secondary compounds.

Based on these results, we inferred that for the doses used in the present study, mainly in the group with the highest concentration ( $37.5 \mathrm{mg}$ of FCT kg $\mathrm{g}^{-1}$ of BW), the metabolism of the nutrients does not represent a problem, given that it did not exceed $1 \%$ of the FCT consumption in lambs.

Several studies have demonstrated the effects of the inclusion of tanniferous plants in diets of animals on the establishment and maintenance of parasite infection (Brunet et al. 2008, Manolaraki et al. 2010, Martínez et al. 2013). At present time, this is an important alternative given that anthelmintic resistance represents a threat for an adequate development of sheep production (Torres-Acosta et al. 2012).

In in vitro studies, the efficacy of $L$. acapulcensis was demonstrated in the reduction of the hatching capacity of eggs, inhibiting the development of larvae from stages $\mathrm{L}_{1} / \mathrm{L}_{2}$ to $\mathrm{L}_{3}$, and also interfered in the migration of $\mathrm{L}_{3}$ (Olmedo et al. 2014);
Fig. 2 Means of ocular mucosa colors (OMC) and packed cell volumes $(\mathrm{PCV})$ in the five experimental groups

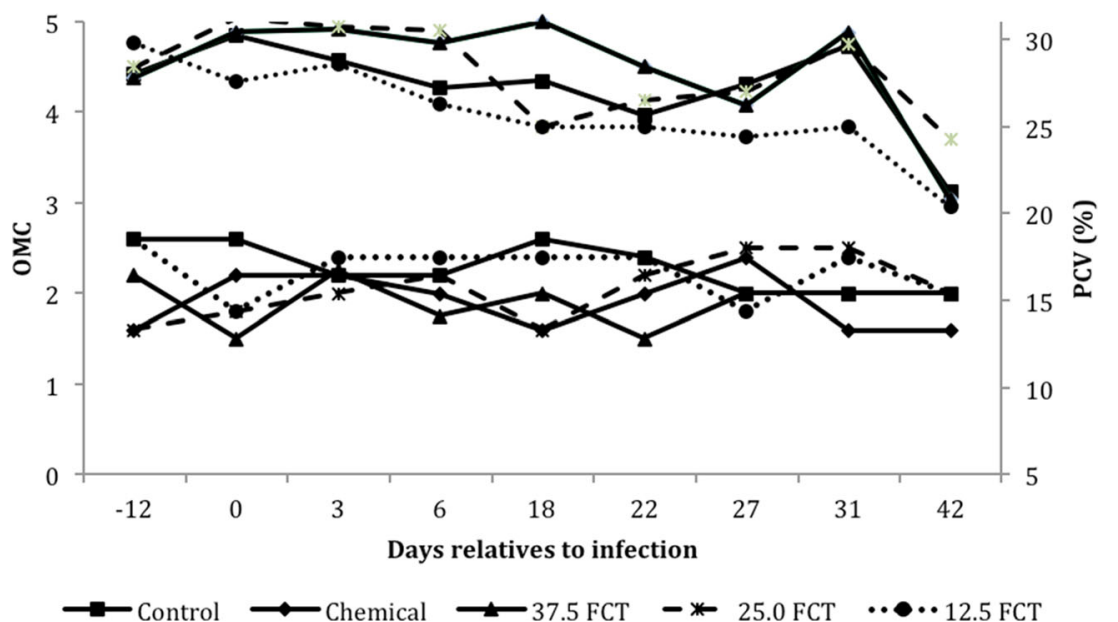


Fig. 3 Average live weight gain in the five experimental groups

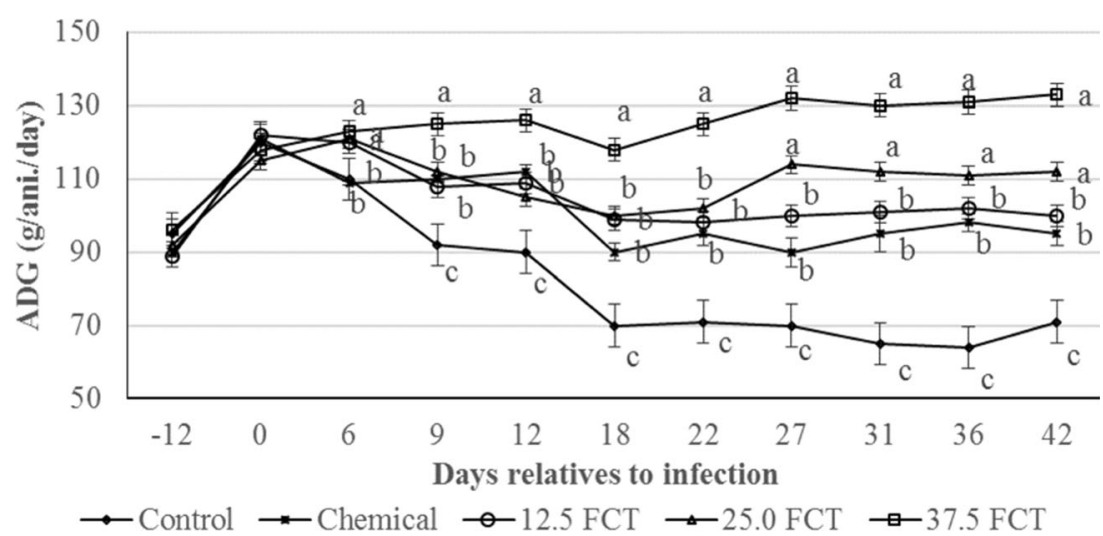

these results make possible to deduce the importance of this plant as a potential species for the control of GIN in extensive productive systems of small ruminants.

Brunet et al. (2008) found that supplementation of fresh foliage of Lysiloma latisiliquum at doses of $1.4 \mathrm{mg} / \mathrm{kg}$ of BW of TCT reduced the establishment of $H$. contortus and T. colubriformis, while Martínez et al. (2013) when administered foliage of the same plant found that in doses of $16.12 \mathrm{~g} /$ day, there was a dramatic reduction in FEC and also in fertility of females of $H$. contortus. These results, along with those obtained in the present study, demonstrate the effectiveness of supplying plants rich in $\mathrm{CT}$ for short periods.

The direct effects are related with structural damage in the adult nematodes that prevented their appropriate feeding, movement, and mating, as was demonstrated by Martínez et al. (2013) in studies using an electronic microscope.

Relative to the efficacy of each group calculated as a function of relative reduction to the control group, it was observed that ivermectine showed an efficacy lower than $95 \%$, which indicates the presence of low resistance or tolerance to this medication (Coles et al. 1992). On the other hand, the group of animals that received the highest dose of FCT showed an efficacy on reduction of FEC higher than $80 \%$ after day 22 post-infection, while in the groups of minimum dose $(12.5 \mathrm{mg}$ of FCT kg ${ }^{-1}$ of BW) and median dose (25.0 mg of FCT kg ${ }^{-1}$ of BW), the efficacy was erratic given that, first, the count was reduced in more than $35 \%$ and reaching values higher than $68 \%$. However, after 36 days, average fecal counts in these groups were higher than those found in the control group. This behavior is probably the result of a response of the parasites to non-lethal doses that interfered in their feeding and egg-laying capacity but did not eliminate them completely. It is likely that during the period of study, the parasites created adaptation mechanisms which started at day 31 , allowing the elimination of eggs through the feces.

In concordance with the present results, a study developed in Brazil reported no effect of the administration of pure marketable extract of Acacia mearnsii on the number of adult parasites. However, the viability of the eggs $T$. colubriformis (Minho et al. 2010) was compromised, a variable that was not evaluated in the present study. It is probable that, in addition to the dose used, there are other factors such as the nature of the tannins and its chemical structure (Min et al. 2003) that could interfere with their general biological activity (Hoste et al. 2006, Quijada et al. 2015).
Fig. 4 Adult nematode (Haemonchus contortus) count in the five experimental groups

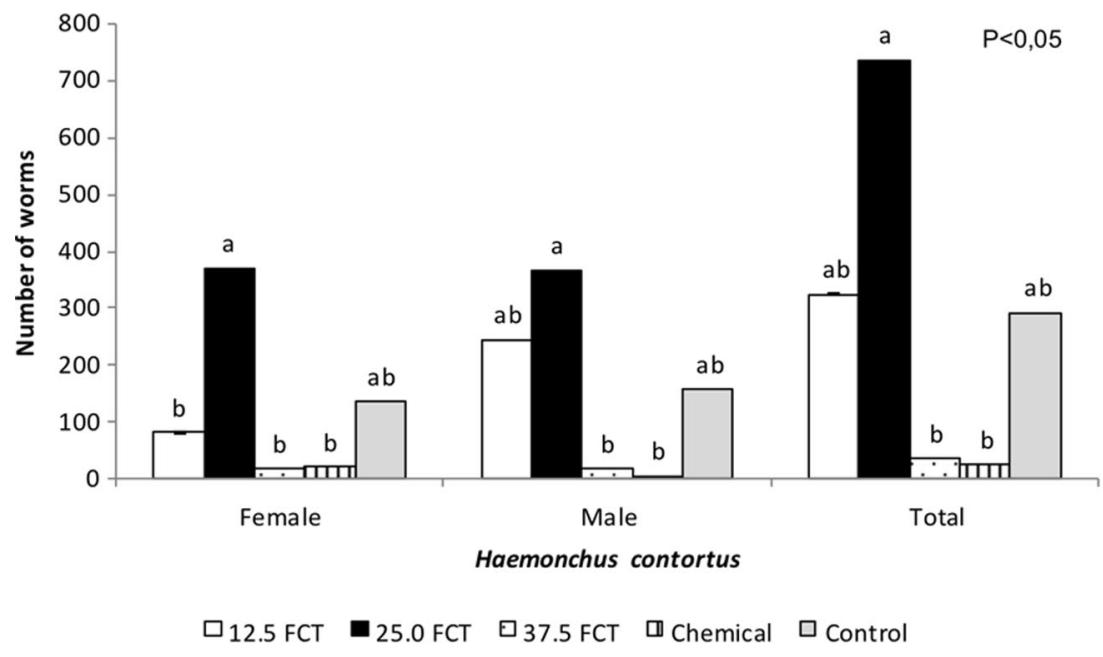




\section{Packed cell volumes and ocular mucosa colors}

The values of PCV and OMC observed did not indicate anemia in the animals; thus, the inoculated dose of larvae did not have significant effect on health and the animals maintained hemostasia; furthermore, the physiopathological changes induced in them are directly related to the nutritional plan to which they were subjected. In this sense, Arece et al. (2013) found that under similar conditions, no important variations in health were detected in the animals.

\section{Live weight gain}

The weight differences observed are probably related to a better use of the protein in the diet as a result of a greater supply of tannins. In rumen, at $\mathrm{pH}$ between 6 and 7, the complexes that form between the FCT and the proteins are stable (Butter et al. 2000) and contribute to protect the proteins from ruminal degradation. The formation of these complexes between the tannins and the dietary proteins or microbial enzymes globally reduces the ruminal proteolysis (Min et al. 2003), favoring the flow toward the abomasum where they are degraded by the gastric juices $(\mathrm{HCl})$ and digestive proteases. This in turn increases the flow of amino acids to the duodenum, which, together with the microbial protein, increases the pool of metabolizable nitrogen compounds, promoting the anabolism of muscular protein.

Probably, if higher doses of FCT were used in the present study, there would be more interference in the use of protein, $\mathrm{NDF}$, and organic matter as a result of the union of the FCTs to the enzymes produced by the ruminal microorganisms, which would also reduce the nitrogen content and consequently would lead to a reduction in the digestion of the potentially degradable fractions (Romero et al. 2000).

The L. acapulcensis had $61.9 \%$ of the CT in free form (FCT), similar to those reported by other trees such as Guazuma ulmifolia (72.2 \%), Leucaena leucocephala (73.8 \%), and Gliricidia sepium (71 \%) (López et al. 2004). This caused the possible effects in the formation of complexes with the diet and endogenous protein to be greater (Scull and Savón 2003), which reflected an improved productive behavior of the animals.

\section{Adult nematode count}

The present study demonstrates the direct effect of tannins on adult parasites by decreasing the egg-laying capacity on one hand and eliminating adult parasites on the other, as a function of the dose used. In the dose of $37.5 \mathrm{mg}$ of FCT kg${ }^{-1}$ of BW, more than $90 \%$ of adult nematodes were eliminated. As previously mentioned, it is probable that this dose caused physical damage to the parasites, preventing their permanence in the digestive system of the animals and caused them to be eliminated in feces. In the lowest dose, reduction registered in egg count was related to variations in the fertility of the parasites as an adaptation mechanism, as other studies have been shown (Mupeyo et al. 2011).

\section{Conclusion}

The dose of $37.5 \mathrm{mg} / \mathrm{kg}$ of FCT of the leaves of L. acapulcensis eliminated the already established parasites and consequently decreased the elimination rate of eggs. In addition, it improved the live weight gain of the male lambs, which demonstrates a nutraceutic effect.

Acknowledgments This work was undertaken with funds from the Universidad Autónoma del Estado de México (Project UAEM 1026/2014RIFC). Our gratitude also goes to the Mexican National Council for Science and Technology (CONACYT) for the grant received by Cesar García Hernández.

\section{Compliance with ethical standards}

Conflict of interest The authors declare that they have no conflicting interests.

\section{References}

Ahmed, M., Laing, M.D., Nsahlai, I.V., 2014. In vivo effect of selected medicinal plants against gastrointestinal nematodes of sheep, Tropical Animal Health and Production, 46, 411-417

AOAC, 1997. Official methods of analysis. 16th ed. Assoc, Official Analytical Chemistry, Arlington, VA

Arece, J., Rojas, F., González, E., Cáceres, O., 2002. Eficacia de labiomec en el parasitismo en ovinos, terneros y equinos en condiciones de producción, Pastos y forrajes, 25, 223-229

Arece, J., López, Y., Molina, M., Alpízar, A., 2013. Cambios fisiopatológicos en ovinos Pelibuey en estabulación, después de infestación experimental con estrongílidos gastrointestinales, Pastos y Forrajes, 36, 354-359

Arece, J., López, Y., Torres-Hernández, G., González-Garduño, R., Rodríguez-Diego, J.G., 2014. Epizootiology of gastrointestinal trichostrongylosis in sheep subject to selective antiparasitic treatments in Cuba, Pastos y Forrajes, 37, 442-448

Brunet, S., Martinez-Ortiz de Montellano, C., Torres-Acosta, J.F.J., Sandoval-Castro, C.A., Aguilar-Caballero, A.J., Capetillo-Leal, C., Hoste, H., 2008. Effect of the consumption of Lysiloma latisiliquum on the larval establishment of gastrointestinal nematodes in goats, Veterinary Parasitology, 157, 81-88

Butter, N.L., Dawson, J.M., Wakelin, D., Buttery, P.J., 2000. Effect of dietary tannin and protein concentration on nematode infection (Trichostrongylus colubriformis) in lambs, Journal Agriculture Science, 134, 89-99

Camacho, L.M., Rojo, R., Salem, A.Z.M., Mendoza, G.D., López, D., Tinoco, J.L., Albarrán, B., Montañez-Valdez, O.D., 2010. In vitro ruminal fermentation kinetics and energy utilization of three Mexican tree fodder species during the rainy and dry period, Animal Feed Science and Technology, 160, 110-120 
Cedillo, J., Kholif, A.E., Salem, A.Z.M., Elghandour, M.M.Y., Vázquez, J.F., Alonso, M.U., Barbabosa, A., Chagoyán, J.C.V., Reyna, A.G., 2015. Oral administration of Sauce llorón extract to growing lambs to control gastrointestinal nematodes and Moniezia spp, Asian Pacific Journal of Tropical Medicine, 8, 520-525

Coles, G.C., Bauer, C., Borgsteede, F.H.M., Geerts, S., Klei, T.R., Taylor, M.A., Waller, P.J., 1992. World Association for the Advancement of Veterinary Parasitology (WAAVP) methods for the detection of anthelmintic resistance in nematodes of veterinary importance, Veterinary Parasitology, 44, 35-44

Debela, E., Tolera, A., Eik, L.O., Salte, R., 2012. Condensed tannins from Sesbania sesban and Desmodium intortum as a means of Haemonchus contortus control in goats, Tropical Animal Health and Production, 44, 1939-1944

Hoste, H., Jackson, F., Athanasiadou, S., Thamsborg, S.M., Hoskin, S.O., 2006. The effects of tannin-rich plants on parasitic nematodes in ruminants, Trends in Parasitology, 22, 253-261

INEGI, 2014. Anuario estadístico y geográfico por entidad federativa, 2014. Instituto Nacional de Estadística y Geografía, Aguascalientes, Aguascalientes, Mexico, $774 \mathrm{p}$

Kommuru, D.S., Whitley N.C., Miller, J.E., Mosjidis, J.A., Burke, J.M., Gujja, S., Mechineni, A., Terrill, T.H., 2015. Effect of sericea lespedeza leaf meal pellets on adult female Haemonchus contortus in goats, Veterinary Parasitology, 207, 170-175

López, J., Tejada, I., Vásquez, C., Garza, J.D., Shimada, A., 2004. Condensed tannins in humid tropical fodder crops and their in vitro biological activity: part 1, Journal of the Science of Food and Agriculture, 84, 291-294

Manolaraki, F., Sotiraki, S., Stefanakis, A., Skampardonis, V., Volanis, M., Hoste, H., 2010. Anthelmintic activity of some Mediterranean browse plants against parasitic nematodes, Parasitology,137, 685696

Martínez-Ortiz de Montellano, C., Fourquaux, I., Brunet, S., TorresAcosta, J.F.J., Sandoval-Castro, C.A., Hoste, H., 2009. Scanning electron microscopy of Haemonchus contortus adults after contact with extracts of two tannin rich plants: Lysiloma latisiliquum and Onobrychis viciifolia. In: World Association for the Advancement of Veterinary Parasitology 2009, Abstract Volume, 8-13 August, Calgary, Canada, pp. 165-166

Martínez, O.C., Arroyo-López, C., Fourquaux, I., Torres-Acosta, J.F.J., Sandoval-Castro, C.A., Hoste, H., 2013. Scanning electron microscopy of Haemonchus contortus exposed to tannin-rich plants under in vivo and in vitro conditions, Experimental Parasitology, 133, 281286

Min, B.R., Barry, T.N., Attwood, G.T., McNabb, W.C., 2003. The effect of condensed tannins on the nutrition and health of ruminants fed fresh temperate forages: a review, Animal Feed Science and Technology, $106,3-19$

Min, B.R., Hart, S.P., Miller, D., Tomita, G.M., Loetz, E., Sahlu, T., 2005. The effect of grazing forage containing condensed tannins on gastrointestinal parasite infection and milk composition in Anjora does, Veterinary Parasitology, 130, 105-113

Minho, A.P., Filippsen, L.F., Amarante, A.F.T., Abdalla, A.L., 2010. Efficacy of condensed tannin presents in acacia extract on the control of Trichostrongylus colubriformis in sheep, Ciencia Rural 40, $1360-1365$
Mupeyo, B., Barry, T.N., Pomroy, W.E., Ramírez-Restrepo, C.A., LópezVillalobos, N., Pernthaner, A., 2011. Effects of feeding willow (Salix spp.) upon death of established parasites and parasite fecundity, Animal Feed Science and Technology, 164, 8-20

NRC, 2007. Nutrient requirements of small ruminants, sheep, goats, cervids, and new world camelids, (The National Academy Press, Washington, DC)

Olmedo, J.A., Rojo, R.R., Arece, G.J., Salem, A.Z.M., Kholif, A.E., Morales, A.E., 2014. In vitro activity of Pithecellobium dulce and Lysiloma acapulcensis on exogenous development stages of sheep gastrointestinal strongyles. Italian Journal of Animal Science, 13, 303-307

Olmedo, A., Rojo, R., Arece, J., Salem, A.Z.M., Morales, E., Albarrán, B., Lee, H.A., Vázquez, J.F., 2015. Lysiloma acapulcensis extract on digestibility and ruminal fermentation of a diet for sheep, Ecosistemas Recursos Agropecuarios 2, 173-182

Porter, L.J., Hrstich, L.N., Chan, B.G., 1986. The conversion of procyanidins and prodelphinidins to cyanidin and delhpinidin, Phytochemistry 25, 223-230

Quijada, J., Fryganas, C., Ropiak, H.M., Ramsay, A., Mueller-Harvey, I., Hoste, H., 2015. Anthelmintic activities against Haemonchus contortus or Trichostrongylus colubriformis from small ruminants are influenced by structural features of condensed tannins, Journal of Agriculture and Food Chemistry, 63, 6346-6354

Roberts, F.H.S. and O'Sullivan, J.P., 1952. Methods for egg counts and larval cultures for strongyles infesting the gastrointestinal tract of cattle, Australian Agriculture Research, 1, 99-108

Romero, L.C.E, Palma, G.J.M., López, J., 2000. Influencia del pastoreo en la concentracion de fenoles totales y taninos condensados en Gliricidia sepium en el tropico seco, Livestock Research and Rural Development. 12, http://www.fao.org/ag/aga/agap/frg/lrrd/lrrd12/4/ rome124.htm. Accessed 29 Aug 2016

Saric, T., Rogosic, J., Zupan, I., Beck, R., Bosnic, S., Sikic, Z., Skobic, D., Tkalcic, S., 2015. Anthelmintic effect of three tannin-rich Mediterranean shrubs in naturally infected sheep, Small Ruminant Research. 123, 179-182

SAS, 2014. SAS Online Doc Version 9.1.3. Cary: SAS

Scull, I., Savón, L., 2003. Determinación de polifenoles totales y taninos condensados en harina de forraje de cuatro variedades de Vigna unguiculata, Revista Cubana de Ciencia Agricola, 37, 403-407.

Steel, R.G.D., Torrie, J.H., Dieky, D.A., 1997. Principles and procedures of statistics, (3rd ed. McGraw Hill Book Co. Inc., New York)

Terrill, T.H., Rowan, A.M., Douglas, G.B., Barry, T.N., 1992. Determination of extractable and bound condensed tannins concentration in forage plants, protein concentrate meals and cereal grains, Journal of the Science of Food and Agriculture, 58, 321-329

Torres-Acosta, J.F., Mendoza-de-Gives, P., Aguilar-Caballero, A.J., Cuéllar-Ordaz, J.A., 2012. Anthelmintic resistance in sheep farms: update of the situation in the American continent, Veterinary Parasitology, 189, 89-96

Van Soest, P.J., Robertson, J.B., Lewis, B.A., 1991. Methods for dietary fiber, neutral detergent fiber, and nonstarch polysaccharides in relation to animal nutrition, Journal of Dairy Science, 74, 3583-3597

Van Wyk, J.A., Bath, G.F., 2002. The FAMACHA system for managing haemonchosis in sheep and goats by clinically identifying individual animals for treatment, Veterinary Research, 33, 509-529 